\title{
IMPLIKASI PERLINDUNGAN PATEN TERHADAP SOFTWARE DI INDONESIA DAN NEGARA MAJU
}

\author{
Devi Cantika \\ 155100018 \\ Fakultas Komputer, 448757182 \\ devicantika.student@umitra.ac.id
}

\begin{abstract}
Di beberapa negara maju seperti Jepang dan Amerika Serikat perlindungan terhadap software dilakukan melalui paten. Di Indonesia, perlindungan software dilaksanakan melalui Hak Cipta. Perlindungan paten terhadap software belum diakui oleh pemerintah. Software atau program komputer dianggap sebagai sebuah ciptaan manusia dalam bidang ilmu pengetahuan komputer namun tidak berkaitan langsung dengan teknologi. Makalah ini akan mengkaji perlindungan software berdasarkan undang-undang di Indonesia. Kami mencoba menganalisa implikasi dari perlindungan software terhadap masyarakat maupun pihak pengembang. Berdasarkan analisa yang dilakukan dapat disimpulkan bahwa belum ada implikasi yang signifikan tentang perlindungan software di Indonesia. Lain halnya dengan negara maju seperti Amerika Serikat, perlindungan terhadap software mendapat perhatian yang cukup besar dari berbagai pihak dan menuai banyak kritikan.
\end{abstract}

Kata Kunci : Implikasi Paten. Software di Indonesia dan Negara Maju. 


\section{A. INTRODUCTION}

Di beberapa negara maju seperti Jepang dan Amerika Serikat perlindungan terhadap software dilakukan melalui paten. Meskipun demikian, sampai saat ini masih banyak perdebatan mengenai software yang dipantenkan di Amerika. Komunitas programmer dan ahli hukum menyatakan bahwa coding yang ada di dalam software dianalogikan sebagai "karya tulis" layaknya seorang novelis membuat sebuah novel.

Di Indonesia, perlindungan software dilaksanakan melalui Hak Cipta. Perlindungan paten terhadap software belum diakui oleh pemerintah. Software atau program komputer dianggap sebagai sebuah ciptaan manusia dalam bidang ilmu pengetahuan komputer namun tidak berkaitan langsung dengan teknologi.

perlindungan software berdasarkan undang-undang di Indonesia, studi literatur yang membahas perlindungan software di dalam maupun luar negeri dan juga melakukan wawancara dengan lembaga perlindungan hak kekayaan intelektual di ITS untuk mendapatkan data empiris terkait dengan perlindungan software.
Kami mencoba menganalisa implikasi dari perlindungan software terhadap masyarakat maupun pihak pengembang. Hasil dari penelitian ini diharapkan dapat mengungkap informasi tentang implikasi dari perlindungan software di Indonesia dan negara maju.

\section{Pengertian Paten}

Untuk memahami konsep dari paten dan berikut akan dijabarkan pengertian keduanya yang diambil dari undang-undang di Indonesia.

a. Paten berdasarkan Undang-undang No. 14 Tahun 2001

Paten : hak eksklusif yang diberikan oleh Negara kepada Inventor atas hasil nvensinya di bidang teknologi, yang untuk selama waktu tertentu melaksanakan sendiri invensinya tersebut atau memberikan pers etujuannya kepada pihak lain untuk melaksanakannya.

Invensi : ide Inventor yang dituangkan ke dalam suatu kegiatan pemecahan masalah yang spesifik di bidang teknologi dapat berupa produk atau proses, atau penyempurnaan dan pengembangan produk atau proses.

Inventor : seorang yang secara sendiri atau beberapa orang yang secara bersama-sama melaksanakan 
ide yang dituangkan ke dalam kegiatan yang menghasilkan Invensi.

Paten diberikan untuk Invensi yang baru dan mengandung langkah inventif serta dapat diterapkan dalam industri. Suatu Invensi dikatakan mengandung langkah inventif jika Invensi tersebut merupakan sesuatu yang baru atau hal yang tidak dapat diduga sebelumnya menurut orang-orang yang mempunyai keahlian tertentu di bidang teknik. Penilaian bahwa suatu invensi merupakan hal yang tidak dapat diduga sebelumnya harus dilakukan dengan memperhatikan keahlian yang ada pada saat Permohonan diajukan. Suatu Invensi dianggap baru jika pada Tanggal Penerimaan, Invensi tersebut tidak sama dengan teknologi yang diungkapkan sebelumnya. Paten diberikan untuk jangka waktu selama 20 (dua puluh) tahun terhitung sejak Tanggal Penerimaan dan jangka waktu itu tidak dapat diperpanjang.

Pemegang Paten memiliki hak eksklusif untuk melaksanakan Paten yang dimilikinya dan melarang pihak lain yang tanpa persetujuannya:

a. dalam hal Paten-produk: membuat, menggunakan, menjual, mengimpor,menyewakan, menyerahkan atau menyediakan untuk dijual atau disewakan atau diserahkan produk yang diberi Paten.

b. dalam hal Paten-proses: menggunakan proses produksi yang diberi Paten untuk membuat barang dan tindakan lainnya sebagaimana dimaksud dalam huruf a. Apabila sesorang ingin menggunakan paten tersebut maka harus membayar royalti kepada pemegang paten.

\section{Perlindungan Software di Indonesia}

Berdasarkan Undang-undang No.

19 Tahun 2002 pasal 12, program komputer atau software termasuk dalam perlindungan Hak Cipta, bukan dengan paten. Perlindungan paten terhadap software hanya ada di negara-negara maju seperti Jepang dan Amerika Serikat. Hal ini diungkapkan pula oleh Prof. Soeprapto selaku Ketua BP2KI di ITS, perlindungan paten terhadap software belum ada di Indonesia. Pengertian dari paten sendiri adalah hak eksklusif yang diberikan oleh Negara kepada Inventor atas hasil Invensinya di bidang teknologi. 
Invensi adalah ide Inventor yang dituangkan ke dalam suatu kegiatan pemecahan masalah yang spesifik di bidang teknologi dapat berupa produk atau proses, atau penyempurnaan dan pengembangan produk atau proses. Contoh dari invensi yang dapat dipatenkan adalah "proses pembuatan tempe". Dalam hal ini, software sebagai sebuah produk atau aplikasi dianggap tidak berkaitan dengan teknologi.

Di BP2KI ITS terdapat beberapa software yang telah didaftarkan Hak Cipta. Namun, ada pula software dari fakultas Teknik Informatika dan Teknik Elektro yang berhasil diajukan paten. Invensi yang diajukan berupa algoritma atau proses untuk memecahkan masalah praktis yang spesifik yang diwujudkan dalam software. Pengakuan paten dari algoritma software ini merupakan suatu hal yang tidak mudah dilakukan dan memerlukan waktu yang cukup lama sampai akhirnya paten diakui. Berdasarkan data tersebut, meskipun software secara langsung tidak dapat dipatenkan namun, algortima atau proses yang berjalan di dalamnya yang berfungsi memecahkan permasalahan praktis yang spesifik masih dapat dipatenkan.

Beberapa software dari ITS yang algoritma, metode atau prosesnya diklaim sebagai invensi paten kami jabarkan pada Tabel 1. Tabel. Paten Algoritma Software dari ITS

\begin{tabular}{|c|c|c|c|c|}
\hline $\begin{array}{l}\mathbf{N} \\
\mathbf{0}\end{array}$ & $\begin{array}{l}\text { Nomor } \\
\text { Permoh } \\
\text { o } \\
\text { nan } \\
\end{array}$ & $\begin{array}{l}\text { Invent } \\
\text { or }\end{array}$ & $\begin{array}{l}\text { Judul } \\
\text { Invensi }\end{array}$ & $\begin{array}{l}\text { Tahun } \\
\text { pengaj } \\
\text { u } \\
\text { an } \\
\end{array}$ \\
\hline 1 & $\begin{array}{l}\text { P002009 } \\
00463\end{array}$ & $\begin{array}{l}\text { Lutfia } \\
\text { na } \\
\text { Ratna } \\
\text { Dewi, } \\
\text { Agus } \\
\text { Zainal } \\
\begin{array}{l}\text { Arifin } \\
\text { dkk }\end{array}\end{array}$ & $\begin{array}{l}\text { Sistem } \\
\text { Diagnosa } \\
\text { Osteoporo } \\
\mathrm{s} \\
\text { is } \\
\text { Berdasark } \\
\text { a } \\
\mathrm{n} \\
\text { Analisa } \\
\text { Kepadata } \\
\mathrm{n} \\
\text { Tulang } \\
\text { Trabecula } \\
\text { e } \\
\text { Pada } \\
\text { Citra } \\
\text { Panorama } \\
\text { Gigi }\end{array}$ & 2009 \\
\hline 2 & $\begin{array}{l}\text { P002009 } \\
00073\end{array}$ & $\begin{array}{l}\text { Abdull } \\
\text { Ah }\end{array}$ & $\begin{array}{l}\text { Metode } \\
\text { Heuristik }\end{array}$ & 2009 \\
\hline
\end{tabular}

Indonesia, ikut dalam Patent Cooperation Treaty (PCT), yang dirancang oleh WIPO (Worle Intelectual Property Oragnization). Dengan adanya fasilitas PCT, mendorong pihak luar untuk mendaftarkan patennya di negara anggota PCT.

Bagi Indonesia, dengan adanya fasilitas ini, akan memacu permintaan pengajuan paten asing, sehingga Indonesia akan mendapat fee dari paten tersebut. [7]

Tapi penerapan paten di Indonesia bukan tanpa masalah. Hukum paten Indonesia, masih menyimpan beberapa permasalahan [7] : 
1. Kesulitan untuk menguji penemuan yang dapat dipatenkan. Hal ini bisa terjadi karena terbatasnya sumber daya ahli di Indonesia.

2. Tidak adanya system database yang lengkap mengenai penemuan yang sudah ada, sehingga sulit untuk menentukanapakahsebuah penemuan itu baru. Padahal, baru atau belum pernah ditemukan sebelumnya merupakan salah satu syarat paten.

3. Masih ada peraturan yang belum dikeluarkan, sehingga peraturan hukum paten menjadi tidak efektif.

4. Adanyaperbedaanpengaturan paten, sehingga menimbulkan konflik

5. Kesadaran inventor untuk mematenkan penemuan mereka masih sangat minim.

6. Masih ada peraturan yang belum dikeluarkan, sehingga peraturan hukum paten menjadi tidak efektif.

7. Adanyaperbedaanpengaturan paten, sehingga menimbulkan konflik

8. Kesadaran inventor untuk mematenkan penemuan mereka masih sangat minim.

\section{Perlindungan Software di negara maju}

Di beberapa negara maju seperti Amerika Serikat dan Jepang, perlindungan terhadap software dilakukan melalui paten. Amerika Serikat adalah negara dengan jumlah paten software terbesar, dan pemimpin dalam produksi software di seluruh dunia. Tahun 2006, terdapat sekitar 30.000 software yang dipatenkan di Amerika. Paten software menjadi masalah perdebatan selama beberapa tahun terakhir.

Berdasarkan penelitian yang dilakukan oleh Bessen dan Hunt (2007) sebagian besar perangkat lunak yang dipatenkan bukan berasal dari perusahaan pembuat perangkatlunak. Hanya1\%dari

perusahaanperangkatlunakyang

mempatenkan produknya. Terdapat lima perusahaan yang memiliki paten terbanyak pada tahun 1995 antara lain IBM, Motorola, Hitachi, AT\&T dan HewlettPackard. Kebanyakan perusahaan yang mempatenkan produknya justru berasal dari perusahaan yang bergerak di bidang industri seperti elektronik, mesin dan perkakas kantor [1]. Tabel 1 menunjukkan beberapa contoh perangkat lunak yang dipatenkan di Amerika :

Tabel 4. Beberapa Paten Software di Amerika 


\begin{tabular}{|l|l|l|l|l|} 
No & Paten & tor & $\begin{array}{l}\text { Keteranga } \\
\mathbf{n}\end{array}$ & $\begin{array}{l}\text { Pengaj } \\
\text { uan }\end{array}$ \\
\hline 1 & $\begin{array}{l}\text { EP1134 } \\
6\end{array}$ & $\begin{array}{l}\text { Hartm } \\
\text { an } \\
\text { Peri }\end{array}$ & $\begin{array}{l}\text { Amazon.co } \\
\text { m } \\
\text { mengklaim } \\
\text { metode } \\
\text { dan }\end{array}$ & 2001 \\
& &
\end{tabular}

\begin{tabular}{|l|l|l|l|l|}
\hline No & $\begin{array}{l}\text { Nomor } \\
\text { Paten }\end{array}$ & $\begin{array}{l}\text { Inven } \\
\text { tor }\end{array}$ & $\begin{array}{l}\text { Keteranga } \\
\mathbf{n}\end{array}$ & $\begin{array}{l}\text { Tahun } \\
\text { Pengaj } \\
\text { uan }\end{array}$ \\
\hline & & & $\begin{array}{l}\text { melal } \\
\text { ui } \\
\text { jaringan } \\
\text { komunikasi. }\end{array}$ & \\
\hline
\end{tabular}

Begitu pula di Eropa, paten software menjadi pembicaraan hangat.

Meskipun berdasarkan konvensi paten di Eropa, program komputer atau software tidak dapat dipatenkan, jika objek invensi yang dimaksud menjelaskan proses yang berkaitan dengan komputer atau benda lain yang berhubungan dengan pemrograman konvensional, objek tersebut dapat diperiksa sebagai "computer-implemented invention” atau invensi yang diimplementasikan pada komputer. Dalam

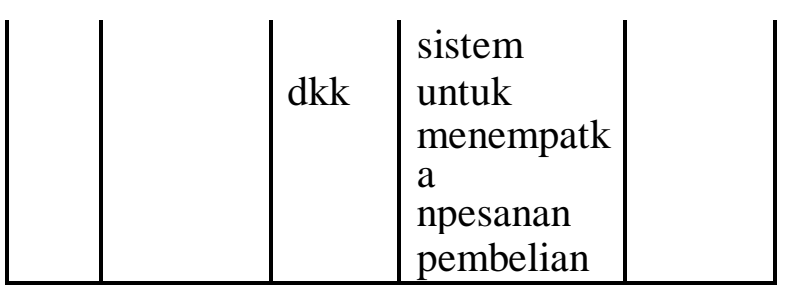

prakteknya, EPO (European Patent Office) mengindikasikan invensi yang "computerimplemented atau dapat di imolementasikan pada komputer dapat dipatenkan karena invensisemacam itu memiliki karakter teknis yang menyelesaikan permasalahan praktis

[2].Tabel 2 memberikan beberapa contoh paten software di Eropa.

Tabel 5. Beberapa paten software di

\begin{tabular}{|l|l|l|l|l|}
\hline No & $\begin{array}{l}\text { Nomor } \\
\text { Paten }\end{array}$ & $\begin{array}{l}\text { Inven } \\
\text { tor }\end{array}$ & $\begin{array}{l}\text { Keteranga } \\
\text { n }\end{array}$ & $\begin{array}{l}\text { Tahun } \\
\text { Pengaj } \\
\text { uan }\end{array}$ \\
\hline 1 & $\begin{array}{l}\text { EP25834 } \\
83\end{array}$ & $\begin{array}{l}\text { Horn } \\
\text { Guent } \\
\text { her }\end{array}$ & $\begin{array}{l}\text { Nokia } \\
\text { Siemens } \\
\text { Network } \\
\text { mengklaim } \\
\text { metode } \\
\text { untuk } \\
\text { membangu } \\
\text { n }\end{array}$ & \\
\hline
\end{tabular}




\begin{tabular}{|l|l|l|l|l|}
\hline No & $\begin{array}{l}\text { Nomor } \\
\text { Paten }\end{array}$ & $\begin{array}{l}\text { Inven } \\
\text { tor }\end{array}$ & $\begin{array}{l}\text { Keteranga } \\
\mathbf{n}\end{array}$ & $\begin{array}{l}\text { Tahun } \\
\text { Pengaj } \\
\text { uan }\end{array}$ \\
\hline & & & $\begin{array}{l}\text { koneksi } \\
\text { aman dan } \\
\text { resm } \\
\text { i antara } \\
\text { smar } \\
t \\
\text { dan card } \\
\text { perangkat } \\
\text { di } \\
\text { jaringan. }\end{array}$ & \\
\hline
\end{tabular}

4. Implikasi Perlindungan Software di Indonesia dan negara maju

Di Indonesia perlindungan terhadap

software belum memiliki pengaruh yang signifikan karena penghargaan masyarakat terhadap karya cipta, dalam hal ini software, masih sangat kurang. Pelanggaran terhadap hak cipta software sering terjadi terutama untuk software terkenal dari luar negeri yang umum digunakan seperti Microsoft Office, Photoshop dll. Sekitar lebih dari $90 \%$ program yang digunakan di Indonesia merupakan program yang disalin secara

illegal [10]. Tindakan
pelanggaran atau tindak

pidana berupa pembajakan tersebut tidak terlepas dari pengaruh tingkat ekonomi yang rendah, ditambah dengan tingkat kesadaran masyarakat untuk menghargai karya cipta pencipta masih kurang dan lemahnya sistem hukum yang berlaku [8]. Dampaknya adalah industri software lokal tidak berkembang [10]

karena ketidakpercayaan produsen software dan investor terhadap pasar.

Perlindungan paten terhadap software meskipun tidak didukung oleh undangundang, namun beberapa software lolos dan mendapat hak paten [9]. Hal ini mengindikasikan bahwa paten pada software belum memiliki persyaratan hukum yang jelas [7].

\section{Pengertian Hak Paten}




\section{Section Class Content}

Istilah paten dapat dikatakan sebagai suatu hak khusus yang diberikan kepada seorang penemu atau si pencipta berdasarkan undang-undang yang berlaku atas permintaan yang diajukan kepada pihak penguasa bagi temuan yang diperolehnya khususnya dalam bidang teknologi, yang dapat diterapkan dalam bidang industri, baik berupa temuan baru, cara memperbaiki sistem kerja lama, atau menambahkan sebuah perbaikan-perbaikan baru dalam cara kerjanya untuk jangka waktu tertentu. Terdapat beberapa pengertian atau definisi mengenai hak paten. Pengertian tersebut dapat dijelaskan sebagai berikut:

1. Berdasarkan Undang-Undang Nomor 14 Tahun 2001 Paten adalah hak eksklusif yang diberikan oleh negara kepada inventor atas hasil invensinya di bidang teknologi, yang untuk selama waktu tertentu melaksanakan sendiri invensinya tersebut atau memberikan persetujuannya kepada pihak lain untuk melaksanakannya. .

a. Pasal 1 Undang-Undang Paten Hak khusus yang diberikan negara kepada penemu atas hasil penemuannya di bidang teknologi yang selama waktu tertentu melaksanakan sendiri penemuannya tersebut atau memberikan persetujuan kepada orang lain untuk melaksanakannya.

b. Menurut Kamus Umum Bahasa Indonesia

Paten berasal dari kata Ocktroi yang dalam bahasa Eropa mempunyai arti suatu surat perniagaan atau izin dari pemerintahan yang menyatakan bahwa orang atau perusahaan boleh membuat barang pendapatannya sendiri (orang lain tidak boleh membuatnya).

c.Subjek Paten 
Ketentuan mengenai subjek Paten ini diatur dalam Pasal 10 UU No. 14 tahun 2001 tentang Paten. Dalam ketentuan tersebut dinyatakan bahwa yang berhak memperoleh paten adalah inventor atau yang menerima lebih lanjut hak inventor yang bersangkutan. Jika suatu invensi dihasilkan oleh beberapa orang secara bersamasama, hak atas invensi tersebut dimiliki secara bersama-sama oleh para inventor yang bersangkutan. Kecuali terbukti lain, yang dianggap sebagai inventor adalah seorang atau beberapa orang yang untuk pertama kali dinyatakan sebagai inventor dalam permohonan.

Pihak yang berhak memperoleh paten atas suatu invensi yang dihasilkan dalam suatu hubungan kerja adalah pihak yang memberikan pekerjaan tersebut, kecuali diperjanjikan lain. Ketentuan tersebut juga berlaku terhadap invensi yang dihasilkan baik oleh karyawan maupun pekerja yang menggunakan data dan/atau sarana yang tersedia dalam pekerjaannya sekalipun perjanjian tersebut tidak mengharuskannya untuk menghasilkan invensi. Inventor yang seperti ini berhak mendapatkan imbalan yang layak dengan memperhatikan manfaat ekonomi yang diperoleh dari invensi tersebut. Imbalan tersebut meliputi :

1. Dalam jumlah tertentu dan sekaligus;

2. Persentase;

3. Gabungan antara jumlah tertentu dan sekaligus dengan hadiah atau bonus;

4. Gabungan antara persentase dan hadiah atau bonus; atau

5. Bentuk lain yang disepakati para pihak.

\section{B. CONCLUSION}

Berdasarkan penjabaran di atas 


\begin{abstract}
Dapat disimpulkan bahwa belum ada implikasi yang signifikan tentang perlindungan software di Indonesia. Lain halnya dengan negara maju seperti Amerika Serikat, perlindungan terhadap software mendapat perhatian yang cukup besar dari berbagai pihak dan menuai.
\end{abstract}

1. Perlindungan Software di Indonesia Berdasarkan Undangundang No.19 Tahun 2002 pasal 12, program komputer atau software termasuk dalam perlindungan Hak Cipta, bukan dengan

paten. Perlindungan paten terhadap software hanya ada di negara-negara maju seperti Jepang dan Amerika Serikat. Hal ini diungkapkan pula oleh Prof. Soeprapto selaku Ketua BP2KI di ITS, perlindungan paten terhadap software belum ada di Indonesia.
2. Perlindungan Software di negara maju.

Di beberapa negara maju seperti

Amerika Serikat dan Jepang, perlindungan terhadap software dilakukan melalui paten. Amerika Serikat adalah negara dengan jumlah paten software terbesar, dan pemimpin dalam produksi software di seluruh dunia. Tahun 2006, terdapat sekitar 30.000 software yang dipatenkan di Amerika. Paten software menjadi masalah perdebatan selama beberapa tahun terakhir.

Begitu pula di Eropa, paten softwre menjadi pembicaraan hangat.

Meskipun berdasarkan konvensi paten di Eropa, program komputer atau software tidak dapat dipatenkan, jika objek invensi yang dimaksud menjelaskan proses yang berkaitan dengan komputer atau benda lain 


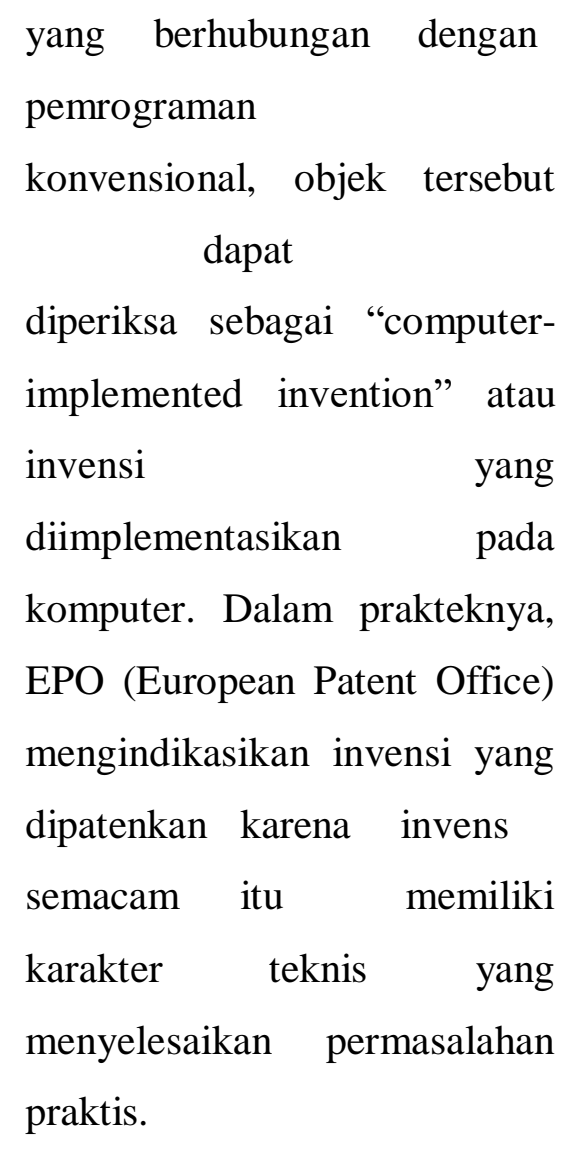

Di Jepang, sistem paten perangkat lunak telah direformasi dan saat ini perangkat lunak menjadi materi yang dapat dipatenkan. Sebelum tahun 1990-an, penemuan terkait dengan perangkat lunak tidak bisa dipatenkan secara mandiri, tetapi

dapat diterapkan dengan mengkombinasikan perangkat lunak pada perangkat keras. Oleh karena itu, perusahaan elektronik yang mengintegrasikan perangkat lunak pada perangkat keras menjadi pematen terbanyak dalam paten perangkat lunak Tabel 3 memberikan beberapa data paten perangkat lunak di Jepang.

\section{Implikasi Perlindungan}

Software di Indonesia dan negara maju
Di Indonesia perlindungan terhadap

software belum memiliki pengaruh yang signifikan karena penghargaan masyarakat terhadap karya cipta, dalam hal ini software, masih sangat kurang. Pelanggaran terhadap hak cipta software sering terjadi terutama untuk software terkenal dari luar negeri yang umum digunakan seperti Microsoft Office, Photoshop dll. Sekitar lebih dari $90 \%$ program yang digunakan di Indonesia merupakan program yang disalin secara 
ilegal. Tindakan pelanggaran atau tindak pidana berupa pembajakan tersebut tidak terlepas dari pengaruh tingkat ekonomi yang rendah, ditambah dengan tingkat kesadaran masyarakat untuk menghargai karya cipta pencipta masih kurang dan lemahnya sistem hukum yang berlaku.

\section{ACKNOWLEDGEMENT University Of Indonesia University Of Mitra Indonesia Telkom University University Of Mellbourne Saitama University}

\section{REFERENCE (Based ISO 690 )}

A. S. Putra And O. M. Febriani, "Knowledge Management Online Application In Pdam Lampung Province," In Prosiding International Conference On Information Technology And Business (Icitb), 2018, Pp. 181-187.

[2] A. S. Putra, O. M. Febriani, And B. Bachry, "Implementasi Genetic Fuzzy System Untuk Mengidentifikasi Hasil Curian Kendaraan Bermotor Di Polda
Lampung," J. Sist. Inf. Dan Manaj. Basis Data, Vol. 1, No. 1, Pp. 21-30, 2018.

[3] O. M. Febriani And A. S. Putra, "Sistem Informasi Monitoring Inventori Barang Pada Balai Riset Standardisasi Industri Bandar Lampung," J. Inform., Vol. 13, No. 1, Pp. 90-98, 2014.

[4] Putra, Arie Setya. "2018 Artikel Struktur Data, Audit Dan Jaringan Komputer." (2018).

[5] Putra, A. S. (2018, July 17). Paperplain Fundamental Create Application With Borland Delphi 7.0 University Of Mitra Indonesia. Retrieved From Osf.Io/Pbrn9.

\section{E. REFERENCE(Based APA )}

Putra, A. S., Aryanti, D. R., \& Hartati, I. (2018, November). Metode SAW (Simple Additive Weighting) sebagai Sistem Pendukung Keputusan Guru Berprestasi (Studi Kasus: SMK Global Surya). In Prosiding Seminar Nasional Darmajaya (Vol. 1, No. 1, pp. 85-97).

Sari, D. P., Febriani, O. M., \& Putra, A. S. (2018, November). Perancangan Sistem Informasi SDM Berprestasi pada SD Global Surya. In Prosiding Seminar Nasional Darmajaya (Vol. 1, No. 1, pp. 289-294).

Putra, A. S. (2018). Paperplain: Execution Fundamental Create Application With Borland Delphi 7.0 University Of Mitra Indonesia. 
Putra, A. S., Sukri, H., \& Zuhri, K. Sistem Monitoring Realtime Jaringan Irigasi Desa (JIDES) Dengan Konsep Jaringan Sensor Nirkabel. IJEIS (Indonesian Journal of Electronics and Instrumentation Systems), 8(2), 221232.

Darmawan, A., Yuliawati, D., Marcella, O., \& Firmandala, R. (2016). Sistem Absensi dan Pelaporan Berbasis Fingerprint dan SMS Gateway. EXPLORE, 7(1).

Febriani, O. M., Wahyuni, T., \& Yusuf, S. (2017). DESIGN OF WEBSITE-BASED INFORMATION SYSTEM FOR EDOCUMENT ADMINISTRASI IN THE COMMUNITY SERVICE UNIT (A Case Study at Rajabasa District). INTERNATIONAL JOURNAL OF COMPUTERS \& TECHNOLOGY, 16(7), 7010-7020.

Febriani, O. M., \& Wahyuni, T. (2017, October). PERANCANGAN SISTEM E-DOCUMENT ADMINISTRASI LOGBOOK PENELITIAN PADA UNIT LAYANAN DI BANDAR LAMPUNG. In Prosiding Seminar Nasional Darmajaya (Vol. 1, No. 1, pp. 187-194).

Febriani, O. M., \& Permadi, A. B. (2017). Implementasi Sistem Aplikasi Data Bimbingan dan Pelanggaran Siswa pada Sekolah Menengah Atas di Lampung Tengah dengan Metode Analisis dan Desain Sistem Terdistribusi (SSAD). EXPERT, 7(1).

Febriani, O. M., \& Ambarwati, L. (2015). PERANCANGAN APLIKASI
PENGOLAHAN DATA PENJUALAN UKM KELANTING KHAS TELO DESA SIDOHARJO KECAMATAN JATI AGUNG KABUPATEN LAMPUNG SELATAN. Jurnal Teknologi Informasi dan Bisnis Pengabdian Masyarakat Darmajaya, 1(1), 77-95.

Febriani, O. M. (2015). Rancang Bangun Aplikasi Ecommercemenggunakan Freewebstore pada UKM Kelanting di Desa Sidoharjo Lampung Selatan. Prosiding Sembistek 2014, 1(02), 446-458. 